\title{
VODNI VIRI BELE KRAJINE
}

Dušan Plut, Tajan Trobec, Barbara Lampič: Regionalni viri Slovenije. Vodni viri Bele krajine. Zbirka E-GeograFF 7. Znanstvena založba Filozofske fakultete Univerze $\mathbf{v}$ Ljubljani in Oddelek za geografijo, 104 str. Ljubljana, 2014

V elektronski zbirki znanstvenih monografij E-GeograFF Oddelka za geografijo ljubljanske Filozofske fakultete je z letom 2014 začela izhajati nova serija publikacij z naslovom Regionalni viri Slovenije, ki želi spodbujati geografsko raziskovanje regionalnih virov $\mathrm{v}$ državi in ga predstavljati tudi širši javnosti. Prva mono-

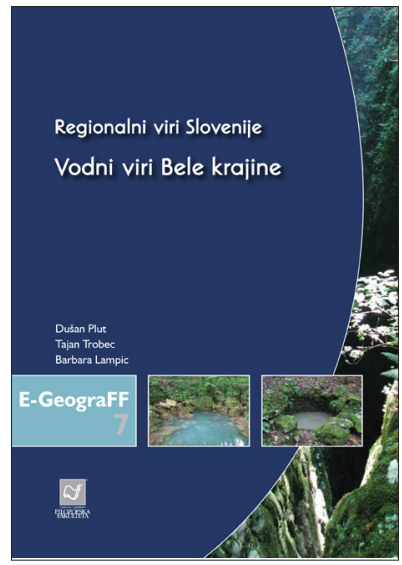
grafija omenjene serije obravnava vodne vire kot izjemno pomemben okoljski vir Bele krajine, ki je bil nekoč ključen poselitveni dejavnik, dandanes pa je lahko razpoložljivost in kakovost vode v kraški pokrajini bodisi razvojna omejitev ali potencial.

V celoviti študiji vodnih virov avtorji uvodoma predstavljajo hidrogeografske značilnosti Bele krajine, s poudarkom na značilnostih porečij belokranjskih voda, hidrogeografskih značilnostih vodotokov in vodni oskrbi območja. V nadaljevanju so prikazani izsledki obsežnega raziskovalnega dela, osnovanega na obširnem terenskem popisu in vrednotenju skupno 261 vodnih virov v vseh treh belokranjskih občinah, Črnomlju, Metliki in Semiču. Avtorji so s pomočjo študentov Oddelka za geografijo na obravnavanem območju popisali 196 izvirov, 48 stoječih površinskih vod (zlasti vaški in hišni kali ter ribniki) in 17 pomembnejših vodnih kraških jam, ki so v monografiji predstavljeni z bogatim slikovnim in kartografskim gradivom. Na številnih zemljevidih so pregledno prikazane popisane značilnosti vsakega izmed raziskanih vodnih virov, mdr. lega z nadmorsko višino, litološka sestava vplivnega območja vodnega vira, površina vodnega telesa pri stoječih površinskih vodah, povprečni pretok v sušnem obdobju leta in stalnost izvirov, vir napajanja stoječih površinskih voda, nekdanja raba vseh popisanih tipov vodnih virov in njihov pomen na začetku 21. st., sodeč po dostopnosti in zaraščenosti. Kljub kraški pokrajini in posledično redki ter slabo razvejeni rečni mreži je bogastvo popisanih vodnih virov veliko, terenska raziskava pa je ob sodelovanju lokalnega prebivalstva pred pozabo zagotovo ubranila mnoge, zlasti tiste, ki v predhodnih preučitvah še niso bili evidentirani in se njihova okolica pospešeno zarašča.

Monografija poleg temeljite predstavitve in vrednotenja značilnosti belokranjskih izvirov, stoječih voda in vodnih kraških jam prinaša tudi analizo vloge vodnih virov skozi čas in preučitev vplivov človekovih dejavnosti nanje. Za prihodnje načrtovanje rabe in varstva vodnih virov so pomembne ugotovitve o neposrednih in posrednih virih obremenjevanja s strani človekovih dejavnosti, pri čemer v največ primerih izstopata kmetijstvo 
in poselitev. Prav ocena posredne in neposredne ogroženosti vodnih virov je bila v nadaljevanju izhodišče za oceno vodnoekološke ogroženosti in skupno oceno pokrajinske ranljivosti evidentiranih vodnih virov. Za oblikovanje slednje so avtorji izdelali tudi oceno hidrogeološke občutljivosti izvirov in vodnih kraških jam. V sklepnem delu bodo za načrtovalce razvoja Bele krajine dragocene predvsem zapisane usmeritve za prihodnje trajnostno upravljanje vodnih virov z izpostavitvijo tistih, ki bi morali biti deležni prednostne obravnave.

Monografija prinaša zanimive in uporabne izsledke tako za lokalno skupnost in zainteresirano javnost kot tudi za tiste, ki iščejo metodološke zglede za podobne preučitve v drugih pokrajinah. Spoznanj ne bi smeli zaobiti niti snovalci gospodarskega razvoja v belokranjskih porečjih niti okoljevarstveniki, ki bi morali pri oblikovanju vodovarstvenih režimov izhajati iz upoštevanja kraške vodnoekološke občutljivosti. V tem pogledu so spodbudna tudi opažanja avtorjev, da se lokalno prebivalstvo ponovno bolj zavzeto zanima za svoje vodne vire, kar se odraža tudi v številnih obnovah lokalnih zajetij, kalov in ribnikov ter prepoznavanju tovrstne naravne in kulturne dediščine. Zagotovo pa bo treba prebivalce še naprej ozaveščati o pomenu vodnih virov za zagotavljanje naravnega ravnovesja, ohranjanje biotske raznovrstnosti in drugih dragocenih ekosistemskih storitev.

$\mathrm{V}$ prepoznavanju in priznavanju strateške vloge vodnih virov za prihodnjo blaginjo prebivalstva in ekosistemov so predstavljena razmišljanja in raziskovalno delo vredni vsega posnemanja, bralcem pa je publikacija v celoti dostopna na spletni strani Oddelka za geografijo Filozofske fakultete: http:/geo.ff.uni-lj.si/sites/default/files/12/e-geograff_7s1.pdf. 